symptoms, but the multiplication of the antigen in them can readily be identified by serological tests or by electron microscopy. This antigen has also been transmitted to some other species of plants; however, the only one in which it has caused any symptoms, and so justifies calling it a virus, is sugar beet, the older leaves of which sometimes become yellow.

Some of the properties of the virus in vitro have been measured by making serological tests on the sap extracted from sweet william plants a month after they were inoculated. Sap from sweet william loses infectivity when diluted more than $1 / 1,000$, the thermal inactivation end-point is between $60^{\circ}$ and $65^{\circ} \mathrm{C}$., and the longevity in vitro at $20^{\circ} \mathrm{C}$. is between two and three days. Sap from the infected sweet william plants contains rod-shaped particles, about $10 \mathrm{~m} \mu$ wide and of varying lengths. These particles closely resemble those previously described in King Edward plants carrying potato paracrinkle virus, which like the carnation virus can infect a range of plants without causing symptoms ${ }^{1}$. Because of these similarities, sap from various potato varieties was tested for its ability to precipitate specifically with the antiserum prepared against the carnation virus. These tests showed that many apparently healthy stocks of potato contain an antigen related to the latent carnation virus. This was not confined to the variety King Edward, which carries potato paracrinkle virus, but was found in plants of the varieties Gladstone, Craig's Alliance, Majestic, Arran Victory, Epicure and U.S. Seedling 41956. Too few tests have yet been made to know how widespread is this virus in potato stocks, but its occurrence in most of the plants already tested suggests that it must be fairly common. In this respect, at least, it resembles a virus recently reported from Holland that is carried symptomlessly by most potato varieties ${ }^{2}$.

B. Kassanis

Rothamsted Experimental Station, Harpenden, Herts. Feb. 15.

'Bawden, F. C., Kassanis, B., and Nixon, H. L., J. Gen. Microbiol., 4, 210 (1950).

${ }^{2}$ De Bruyn Outboter, M. P., Proc. Conf. Potato Virus Diseases, Wageningen-Lisse (1951)." Rozendaal, A., Meded. N.A.K., 8, 94 (1952)

\section{Steroidal Sapogenins in Amazonian Plants}

THe relatively simple method of analysis recently described by Wall, Eddy, McClennan and Klumpp ${ }^{1}$ for the analysis of plant samples for steroidal sapogenins inspired $\mathrm{m} \theta$ to search for them in the rich Amazonian flora. Dr. João Murça Pires, chief of the Botanical Section of this Institute, collected various plant samples which might contain steroidal sapogenins. The results of analysis are given in the accompanying table. Every plant analysed contains more than 0.2 per cent sapogenins. Some of the plants occur in Amazonia in abundance. The 'aninga' (Montrichardia arborescens), for example, is growing so luxuriantly on the banks of the rivers that sometimes the plants represent real obstacles to navigation.

Further work is in progress, and search continues for steroidal sapogenins, which will be identified spectrophotometrically ${ }^{2}$. The results will be published in full elsewhere. amazonian Puants containing Steroidal Sapogeniss

\begin{tabular}{|c|c|c|c|}
\hline Eamily & Scientific name & Part & $\begin{array}{l}\text { Sapogenins } \\
\text { calculated on } \\
\text { absolutely } \\
\text { dry material } \\
\text { (per cent) }\end{array}$ \\
\hline Alimaceae & Sagiltaria sp. & leaves & $0 \cdot 74$ \\
\hline Amarylidaceae & Fourcroya & leaves & 0.83 \\
\hline ", & Smilax sp. & $\begin{array}{l}\text { tubers } \\
\text { roots }\end{array}$ & $\begin{array}{l}0.47 \\
0.50\end{array}$ \\
\hline Araceae & Montrichardia & leaves & 0.69 \\
\hline Bignoniaceae & arborescens & stalks & $0 \cdot 69$ \\
\hline Connaraceae & $\begin{array}{l}\text { Rocarana ligulata } \\
\text { Rourea }\end{array}$ & leaves & $\begin{array}{l}0.43 \\
0.59\end{array}$ \\
\hline Convolvulaceae & Ipomoea fistulosa & $\begin{array}{l}\text { twigs } \\
\text { twigs }\end{array}$ & $\begin{array}{l}0.46 \\
0.29\end{array}$ \\
\hline Dioscoreacea & Dioscorea sp. & tubers & $1 \cdot 65$ \\
\hline Iridaceae & Eleutherina plicata & $\begin{array}{l}\text { leaves } \\
\text { tubcrs }\end{array}$ & $\begin{array}{l}0.54 \\
0.68\end{array}$ \\
\hline Leguminosae & Clitoria javitensis & leaves & $\begin{array}{l}1.29 \\
1.10\end{array}$ \\
\hline$"$ & Derris latifolia & $\begin{array}{l}\text { leaves } \\
\text { roots }\end{array}$ & $\begin{array}{l}0.75 \\
0 \cdot 64\end{array}$ \\
\hline$"$ & Derris negrensis & leaves & $1 \cdot 69$ \\
\hline ", & Derris pterocarpa & $\begin{array}{l}\text { twigs } \\
\text { leaves }\end{array}$ & $\begin{array}{l}0.84 \\
0.80\end{array}$ \\
\hline 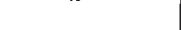 & & roots & 0.91 \\
\hline ", & Derris reviflora & $\begin{array}{l}\text { leaves } \\
\text { roots }\end{array}$ & $\begin{array}{l}1 \cdot 28 \\
1 \cdot 16\end{array}$ \\
\hline " & Derris urucu & leaves & 0.57 \\
\hline " & Derris utilis & $\begin{array}{l}\text { roots } \\
\text { leaves }\end{array}$ & $\begin{array}{l}0 \cdot 47 \\
0 \cdot 49\end{array}$ \\
\hline 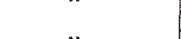 & & roots & 0.73 \\
\hline$"$ & $\begin{array}{l}\text { Pithecolobium cauli- } \\
\text { florum }\end{array}$ & bast & $2 \cdot 31$ \\
\hline Malphigiaceae & Stigmaphyllon fulgens & leaves & $\begin{array}{l}0 \cdot 43 \\
0 \cdot 51\end{array}$ \\
\hline " & Mascagnia sepium & leaves & $0 \cdot 24$ \\
\hline Malphioceae & Banisteria caapi & leaves & 0.57 \\
\hline Sapindaceae & Sapindus saponaria & fruit-pulp & 1.05 \\
\hline
\end{tabular}

I wish to acknowledge my indebtedness to Felisberto C. de Camargo, director of the Serviço Nacional de Pesquizas Agronômicas of the Brazilian Ministry of Agriculture, for his interest in this work, and for permission to publish the results obtained. Thanks are also due to M. E. Wall, J. M. Pires and Luiz Mergulhão.

Chemical Section,

R. F. A. Altman

Instituto Agronômico do Norte, Belém, Brazil. Jan. 23.

1 Wall, M. E., Eddy, C. R., MLClennan, M. L., and Klumpp, M. E. Anal. Chem., 24, 1337 (1952).

${ }^{2}$ Cf. Eddy, C. R., Wall, M. E., and Klumpp Scott, M. E., Anal. Chem., 25, 266 (1053)

\section{Observations on the Iodo-Amino-Acids of Marine Algae using lodine-|3|}

IoDINe has been reported to occur in marine alga as inorganic iodide and iodo-tyrosines ${ }^{1}$. Both forms are known to produce artefacts under chromatographic examination ${ }^{2,3}$. It therefore appeared desirable to examine the chemical stability of the iodine atoms in iodo-amino-acids and their exchangeability with radioactive iodide under the conditions of hydrolysis with barium hydroxide before attempting to investigate the metabolism of iodine fixation in the algae.

The chemical stability of the compounds was found by comparing chromatograms of the substances remaining after barium hydroxide treatment with those of the starting materials, the acids being made visible by spraying with ninhydrin. The exchangeability of the iodine atoms was determined by autoradiography. If simple exchange occurred, radio- 